\title{
Environmental Studies
}

Students of Environmental Studies at the University of Oslo began their semester with a weeklong hike over the scenic Hardangervidda mountain plateau. ${ }^{\mathrm{I}}$ It was an outdoor experience designed to take the students away from the capitalist and industrial setting of the city and deep into the periphery of a picturesque nature, thus beginning their studies with the right state of mind. Empowered by the mountains, they could enter the valleys of industrialism and shallow ecological thinking with a dogooding gaze of knowing what's right from wrong. Their guide was the ecophilosopher Nils Faarlund, who told the students that being outside in nature was actually being truly inside. The trip was organized by Rådet for natur- og miljøfag ("The Council for Nature and Environmental Studies"), hereafter only Environmental Studies. ${ }^{2}$ The institution became the intellectual think tank for the Deep Ecologists who were caught in the middle of the Cold War divide at that time. They were under attack from both Marxists, who saw them as counter-revolutionary, and supporters of the European Community, who thought they were unable to appreciate international cooperation empowered by capitalism. These tensions would energize and radicalize Environmental Studies scholars toward a more ideological vision of a future world in ecological equilibrium. This chapter will review the work of Environmental Studies and, by doing so,

I Anonymous, "God generalprøve for Miljøfagseminaret," Nytt fra Universitetet i Oslo, no. 5 (I975), 2, UO.

${ }^{2}$ Paul Hofseth, Rådet for natur- og miljøfag: Rapport fra virksombeten 1972-75 (Oslo: Rådet for natur- og miljøfag, I975); Rådet for natur- og miljøfag: Rapport fra virksombeten $1972-78$ (Oslo: Rådet for natur- og miljøfag, I978). 
discuss how this field established itself in Norway. Despite the Marxist attacks described in the previous chapter, it is important to note that the I970s was a decade of intellectual confidence among the Deep Ecologists. The fact that the nation had rejected membership of the European Community in September 1972 loomed large in how they came to frame the field. Could Environmental Studies point out an alternative direction for the nation other than communism and consumer capitalism? As the vanguard of social change, the scholars associated with Environmental Studies saw themselves as harboring an environmental vision for Norway that could inspire the world. This was a vision that came to a standstill after the failure to save the Alta-Kautokeino River from hydropower development in 1982. This chapter will revisit that hopeful decade, focusing first on the ethical aspirations, then on the research, and finally on their educational program. As will be apparent, Environmental Studies would in this period grow into the leading institution educating Norwegian politicians, scholars, bureaucrats, and activists in the topic. Indeed, more than 2,000 students would attend their introduction seminar, while a significant number would participate in their re-education program for high-school teachers and college tutors or also take various advance courses.

As discussed in Chapter 3, in June 1972, the Academic Collegium at the University of Oslo had established Environmental Studies as an interdisciplinary institution reporting directly to the University President and not to a particular school, faculty, or department. ${ }^{3}$ It was led by key members of the Ecophilosophy Group who began shaping Environmental Studies in the fall of 1972 with the aim of welcoming their first students within a year. Their first employee was Paul Hofseth who as a teaching assistant in philosophy had published a set of exercises in logic for freshmen students, written together with Sigmund Kvaløy and another lecturer in philosophy. ${ }^{4}$ As a graduate student of philosophy Hofseth had been an active Deep Ecologist with an interest in pollution. He had been a member of the Ecophilosophy Group since its inception, and, as the administrative leader, he placed ecophilosophy at the core of the Environmental Studies curriculum. The institution had initially only two offices, and based their courses and activities on a series of guest lecturers and

3 Anonymous, "Rådet for natur- og miljøfag," Nytt fra universitetet i Oslo, no. I I (I972), 6, UO. Environmental Studies was led by Anne Bjørnebye, Gunnar Brostigen, Aanund Hylland, Terje Lind, and Sigmund Kvaløy. Anonymous, "Natur og menneske," Forskningsnytt, I8, no. 6 (1973), 24.

4 Paul Hofseth, Ola Hole, and Sigmund Kvaløy, Logikkoppgaver til Arne Noess: en del elementore logiske emner (Oslo: Universitetsforlaget, I968-1973). 
seminar leaders from various departments within the University and beyond. This made the tiny institution exciting for the students, but a logistical challenge for Hofseth and his administrative aide, the student of philosophy Arne Vinje (b. I95I). Together they fostered a communal culture of staff, faculty, and students working together, as in having shared lunches, along with parties and even an orchestra. Despite the gravity of the eco-crisis, Environmental Studies was a fun and exciting place to be.

\section{ECOLOGY, COMMUNITY, AND LIFESTYLE}

A regular lecturer at Environmental Studies was the philosopher Arne Næss, who, for the rest of his life, would think of it as his academic home. He was welcomed with open arms, and quickly gained the status as their intellectual leader. In that capacity he began formulating an alternative eco-friendly philosophy for the new field. It was a green vision for how Deep Ecologists and Environmental Studies should guide policies and lifestyles away from self-induced ecological destruction.

Anyone seeking Næss's serious attention, however, would not necessarily find him at the University of Oslo, but instead at his beloved mountain cabin Tvergastein, where he spent much of his time philosophizing. Having had a cup of tea with him at his cabin indicated whether a faculty member or student had been willing to, quite literally, walk that extra mile in pursuit of the answers to deeper philosophical questions. Indeed, a visit entailed a four-hour train ride and two-hour hike (each way). Visits were by invitation only, so having been at his cabin became a secret handshake of acceptance by Næss, which provided access to the inner circle of Deep Ecologists. Visiting Næss's Tvergastein was like an initiation reserved for the chosen ones among environmentally inclined scholars, students, and activists. His self-fashioning as a mountain sage became a tool separating friends from foes, the deep from the shallow, as it was hard to gain respect or move forward in the emerging field of Environmental Studies without having taken ecophilosophy seriously and also having been a guest at his cabin. In the process, Tvergastein gained the status as Environmental Studies' mythical locus.

At Tvergastein, at the Hallingskarvet peak, the philosopher laid out what he thought should be the main principles for the Deep Ecologists. Næss named his philosophy "Ecosophy T" to signal that it was his personal view, and he encouraged other environmentalists to formulate their own ecophilosophies A, B, or C, (though few did). The "T" was short for Tvergastein 
or also tolkning (interpretation) as this was important to Næss's early philosophy. The " $T$ " also gave the equation he had used while vacationing at Tirich Mir a decade earlier a new meaning. The $T=G^{2} /\left(L_{S}+\AA_{s}\right)$ formula stated that $\mathrm{T}$ (for trivsel - "thriving") or self-realization equaled excitement squared divided by bodily and spiritual pains. ${ }^{5}$

Tvergastein offers an extraordinarily deep panoramic weltanschauung. Næss felt small looking out at the overwhelming and vast scenery, an experience that reflects the central distinction in Ecosophy $\mathrm{T}$ between the Self (with capital S), representing all beings in the world, and the biotic self (with a lower-case s), representing only the individual. ${ }^{6}$ True Selfrealization, Næss argued, presupposed the unfolding of the biotic self in harmony with the selfhood of other living beings. Unlike egodevelopment, self-realization presupposes the unfolding of the true ecological self identifying with the selfhood of others within the Self. There are elements from Benedict de Spinoza's philosophy that appeared in Næss's thinking, such as Spinoza's famous "Whatsoever is, is in God, and without God nothing can be, or be conceived." 7 Næss's philosophy implied an opposition to notions of stewardship of the Earth, because stewardship views the world as a collection of natural resources laid out primarily for human use. In this imagined community, the interests of the majority are constituted by non-human populations, which reflect the fact that Næss spent much of his time alone on the mountain peak. The primacy of wilderness was another important feature of his thinking, along with a celebration of place and belonging, and identification with plants, insects, animals, and indigenous peoples, especially the Sherpa. In short, it was a vision of a future in which the wolf would live with the lamb and the bears with the humans in a mixed community of collective Self-realization. ${ }^{8}$ The notion of having a self within a larger Self became important for the Deep Ecological aspiration of being true global citizens within a local community.

Ecosophy T marked a normative mode of theorizing: There is a problem that needs to be solved and therefore a vision of a better order needs

5 Næss, Opp stupet, p. I 26; Økologi, samfunn og livsstil, 5th ed., p. 78.

${ }^{6}$ Næss, Økologi, samfunn og livsstil, 5th ed., pp. 264-322.

7 Benedict de Spinoza, Ethics, in Works of Spinoza, vol. I, R. H. M. Elwes (trs.) (New York: Dover Pub., I955), p. 55 (EIPI 5 ). Arne Næss, Freedom, Emotion and Self-subsistence: The Structure of a Central Part of Spinoza's Ethics (Oslo: Universitetsforlaget, 1975), I I-30; "Environmental ethics and Spinoza's ethics," Inquiry 23 (I980), 3 I3-25.

8 Arne Næss, "Self-realization in mixed communities of humans, bears, sheep, and wolves," Inquiry, 22 (I979), 23 I-4I. 
to be promulgated. As Næss saw it "ecosophy" was a normative as opposed to a descriptive "ecophilosophy," though few of his colleagues adopted the distinction. In opposition to the "shallow" approach (concerned primarily with the reduction of environmental damage), he proposed a program of global rescue based on a radical change in the Western world view from hierarchical and anthropocentric to egalitarian and eco-centric. According to Næss, there was an inseparable connection between the human subject as defined in the Western liberal tradition of philosophy and the environmental havoc unleashed by the competitive lifestyle in the industrial society, such as in the European Community. $\mathrm{He}$ linked the realization of the liberal private sphere directly with material consumption and to a striving for goods, which prevented the Selfrealization of the biosphere. According to Næss, the liberal focus on private self-realization leads to passivity, both with regard to the environment and to the underprivileged: “Liberalism' [is] a norm for nonintervention when a group or a class bleeds, exploits, domineers or manipulates another group or class - or even threatens to exterminate it. As in a wrestling match with no holds barred, such processes must, according to this liberalism, be left to the free interplay of forces - hence the word 'liberal', Latin for 'free'." 9 This rather simplistic Marxist critique was soon transcended into arguments in favor of communitarian lifestyle politics, such as lifestyles predicated on a system of norms outlining the model of a good life in a good biotic community. This community would also include non-human beings, even landscapes and entire ecological systems, as humans to Næss were, like all other living species, just "knots in the biospherical net or field of intrinsic relations." "To This was a hermeneutically useful image reflecting abstract ecology in which relationships replace individuals. Yet the image of humans as knots in fields of relationships came to haunt Næss's thinking, as the value put on individual life in societies that perceive their members as nodes, units, or tributaries of a larger whole has not been very high, critics would argue (in Chapter 9).

Næss's communitarian thinking holds at its core the importance of identification with everyone and everything, especially the oppressed. "[T] he positive appraisal [of individuality] becomes meaningful only within a value system in which norms for the expression of individuality and for collectivism (in several senses of the word) are allowed to confront

9 Næss, Økologi, samfunn og livsstil, 5th ed., p. 320.

Io Næss, "The Shallow and the Deep" (I973), p. 95. 
each other and a ranking of values is suggested." ${ }^{\text {I }}$ The implication was that the individual character would be seasoned by activism and enriched by diversity within groups with a collectivist ideology. Provided that individual peculiarities are not in conflict with the aims of the group, one may show individuality within a collective. Individuality is essential but only on the condition that one is part of an ecological community. "Distinctive, individual traits ... are enforced and intensified in collectivistic-ideological groups, e.g. in a kibbutz." ${ }^{\text {22 }}$ Diversity should therefore be understood as a biotic diversity and diversity within the Deep Ecology movement, but not necessarily as diversity of opinions and lifestyles within a state. The liberal notion of the self-realization of the private sphere alienates men and women from the entirety of the biosphere. Therefore, attempts to solve environmental problems within the framework of private realization inevitably remain "shallow" solutions. This does not mean, however, that when confronted with individuals obsessed with themselves and material goods, Næss would embark on moralizing reprimands. Næss tended to employ strategies of encouragement, even subtle "bribery," to get the holders of shallow views onto his side. His philosophy was not meant to be an instrument for punishing opponents. It is telling that he in his lectures was fond of quoting this line from Spinoza: "I say it is part of a wise man to refresh and recreate himself with moderate and pleasant food and drink, and also with perfumes, with the soft beauty of growing plants, with dress, with music, with many sports, with theatres, and the like, such as every man may make use of without injury to his neighbor." ${ }^{33}$

Accordingly, at Tvergastein, Næss would enrich himself by studying a minute plant, patch of moss, or beautiful rock, smell and drink a sumptuous herbal tea, and enjoy the physical and emotional pleasure of climbing a mountain. The distinction between deep and shallow ecology reflected whether one was able to absorb and appreciate the joys of the local environment. Indeed, his deep ecological critique of modernity centers around the troubling advancement of a civilization lacking in such appreciations, which in his local context meant more disturbing weekend cottages and new roads, as well as the monstrous hotel below in the Ustaoset valley. Yet Næss did not reflect sufficiently on the irony that even the deep ecologist depended on the icon of

${ }^{11}$ Næss, Økologi, samfunn og livsstil, 5th ed., p. 32 I.

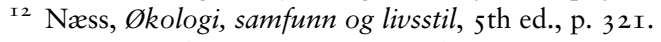

${ }^{13}$ Spinoza, Ethics, p. 2 I9 $_{9}\left(\mathrm{E}_{4} \mathrm{P}_{45} \mathrm{Sch}\right)$. 
modernity, the train, the very symbol of an advancing civilization, to get back to the University of Oslo.

Næss published his concept of Ecosophy $\mathrm{T}$ in what became one of his most celebrated books, namely Økologi, samfunn og lifsstil (Ecology, Community, and Lifestyle), which appeared in five different editions. The first three editions entitled Økologi og filosofi (Ecology and Philosophy) appeared between 197I and 1973, and were in the format of intramural manuscripts capturing the collaborative work of the Ecophilosophy Group (see Chapter 3). ${ }^{\mathrm{I}}$ Here his "ecosophy" of identification and unity with nature would appear in the last chapter, more as an afterthought than as a methodology for the book. This schism would continue in the two subsequent editions with the new title, Økologi, samfunn og lifsstil, which appeared in 1974 and 1976, in which Næss would elaborate mostly on ecological perspectives in relation to social sciences.

The book is a tour-de-force, addressing a range of environmental issues discussed in Norway and other parts of the world in the mid-r97os. It includes a chapter about moving from large-scale technology to small "soft" technology for the benefit of local communities. There is a long chapter critiquing capitalist economic growth in which Næss argues for moving toward a zero-growth society in order to protect the environment. An even longer chapter reviews various eco-political and sociological arguments Næss thought favored ecological protection. There is also a short and sharp chapter about philosophy of science where Næss explains why science can't be value neutral with respect to the ways in which it describes nature. And Næss discusses much more, before he finally presents his Ecosophy $\mathrm{T}$ at the end. The book is remarkable in that it summarizes and discusses contributions from Norwegian environmentalists and links these to ongoing debates in the larger English-speaking community. He thus offers the reader a more or less complete review, or "cavalcade" according to one reviewer, of the environmental debate as he saw it. ${ }^{\text {I5 }}$ The fact that the book was unevenly written gave it a flavor of authenticity and of it coming from a true philosopher.

Ecosophy T was Næss's personal contribution and, as a consequence, had an element of armchair philosophy written at Tvergastein. The rest of the book, however, reflected group work over several years from of the Deep Ecology movements, the Ecophilosophy Group, and debates within

${ }^{14}$ Næss, Økologi og filosofi, I-3 ed.

I5 Tor Inge Romøren, "Økologi, samfunn og livsstil” (review), Norsk filosofisk tidsskrift, 9, no. 4 (I975), I79-80. 
Environmental Studies. Though Næss's name was on the cover, the circle of people around him still felt a sense of ownership over the volume as it captured values and ideas shared among the Deep Ecologists. ${ }^{16}$ Næss had a warm and inclusive personality that drew people in to working with him and supporting the book as it evolved. Among activists and scholars the book came to serve as the intellectual focal point and academic framework for future steps. Indeed, the book was one of only three books required on the syllabus for the Environmental Studies introduction course, discussed below. Criticism of the book would therefore come from those who were not involved in either its inception or its legacy. ${ }^{17}$

It was not only as an author but also as an editor that Næss mobilized for the environment. As a founding editor of Inquiry, Næss enjoyed respect in the wider academic world for facilitating a well-respected interdisciplinary journal of philosophy and the social sciences. It included early contributions by notable people in philosophy such as Charles Taylor, Donald Davidson, and Jürgen Habermas. Næss would use the journal to promote Deep Ecology, as he did when publishing a "summary" of the movement's philosophy back in 1973 (see Chapter 3). More generally, Inquiry would be the launching pad for key early contributions in environmental ethics (John Rodman, Richard Routley (later Sylvan), Genevieve Lloyd), environmental restoration (Robert Elliot), animal liberation and rights (Peter Singer, Colin McGinn, Stephen R. L. Clark, Tom Regan), and environmental history (J. Donald Hughes). ${ }^{\mathrm{I}}{ }^{8}$ The inclusion of articles in Inquiry by these important scholars, often at an early stage in their respective academic careers, was done in the spirit of trying to empower the environmental movement around the world.

If Næss was Environmental Studies' chief philosopher, then Kvaløy was their chief ideologist. His manuscript Øko-filosofisk fragment (Ecophilosophical fragment) was the second required reading for all its

${ }^{16}$ Edvard Barth, "Arne Næss med ny filosofi," VG, Nov. 27, I974, PA.

${ }^{17}$ Dafinn Føllesdal, "Økologi og økonomi” (review), Kirke og kultur, 80 (1975), 23 I-2.

I8 John Rodman, “The liberation of nature?” Inquiry, 20 (I977), 83-I 3 I. Genevieve Lloyd, "Spinoza's environmental ethics," Inquiry, 23 (I980), 293-3 I I. Robert Elliot, "Faking nature," Inquiry, 25 ( 1982 ), 8I-93. Richard Routley, "Alleged problems in attributing beliefs, and intentionality, to animals," Inquiry, 24 (I98I), 385-4I7. Peter Singer, "Killing humans and killing animals," Inquiry, 22 (I979), I45-56. Colin McGinn, "Evolution, animals, and the basis of morality," Inquiry, 22 (I979), 8I-99. Stephen R. L. Clark, "The rights of wild things," Inquiry, 22 (I979), I7 I-88. Tom Regan, "An examination and defense of one argument concerning animal rights," Inquiry, 22 (I979), I89-2 I9. J. Donald Hughes, "Ecology in ancient Greece," Inquiry, I8, no. 2 (I975), II $5-25$. 
students. Just as Næss's book evolved in various editions, Kvaløy's manuscript would also grow over the years with the $4^{\text {th }}$ version from I973 being the one most widely circulated. ${ }^{19}$ To get a copy one had to turn to Vinje, the administrative aide, who printed out the manuscript in its various stages upon request on the Environmental Studies' copy machine. Like nature itself, the book was never finished, but in constant evolution. This gave the reader a sense of being involved in the making of philosophy, in the process of Kvaløy's thinking. And it made him immune to the critic waiting for the final edition to be published so that it could be reviewed and critiqued. Kvaløy, it is worth recalling, was the prime mover behind the Mardøla and Alta demonstrations and the unofficial charismatic leader of the Deep Ecologists. Having a copy of his manuscript signified exclusive membership to an intellectual community.

Despite the ever-changing nature of the manuscript, his ecophilosophy was stable and transparent. At the core was a plea for the survival of the complexity of nature's life force within ecosystems. As he saw it, the nature's complex life force was being destroyed by the industrial society represented by the European Community and the United States. The industrial society model may look "complicated," but it is actually lacking in ecological complexity, he argued. The "complicated" industrial society is one-dimensional and uses standardized movement in mechanical time, while the "complex" ecological society is multi-dimensional, dynamic, and moves in biological time, as in the case of the Beding village in Nepal. In his lectures to a more theoretically oriented audience, he would focus on the difference between complexity and complication, though even highly skilled philosophers would find the distinction bewildering. Surely, there must be complexity in complication and complication in complexity? ${ }^{20}$ Indeed, Kvaløy would struggle formulating an ecophilosophy that gained recognition among academics. He was more effective in communicating to environmental activists the difference between the Life Necessities Society and the Industrial Growth Society. Using an overhead projector he would, as an artist, support his view with dramatic drawings of a harmonious and beautiful Life Necessities Society

I9 Kvaløy, Øko-filosofisk fragment, I972-1973, manuscript in different versions evolving from 43 to 173 pages. Last known version published as Mangfold og tid (Trondheim: NTNU Department of Music, 200I).

${ }^{20}$ Witnessed at the Melbu Conference, July 23, I990, with distinguished thinkers such as Karl-Otto Apel, Matthias Kettener, and Hans Jonas. In Audun Øfsti (ed.), Ecology and Ethics: A Report from the Melbu Conference, I 8-23 July 1990 (Trondheim: Nordland Akademi for Kunst og Vitenskap, I992). 
juxtaposed with images of the nightmarish and polluted Industrial Growth Society, asking rhetorically which one people preferred.

Kvaløy's distinction between the Life Necessities Society and the Industrial Growth Society became an effective way of framing the environmental debate among Deep Ecologists. The distinction evoked a Lutheran pietist condition of guilt necessary for offering an ecological awakening and redemption for environmentalists. As a result, scholars within Environmental Studies would typically debate whether or not something supported the Life Necessities Society, whether that was building or not building an electric power station or dam, prospecting or not prospecting for petroleum, supporting a society propelled by economic growth or living in a society with economic equilibrium, etc. These debates were cast in bipolar dichotomies, typical for the Cold War period, and Kvaløy would use his authority to make sure the Deep Ecologists did not drift toward the middle ground, but rather stayed put with their do-gooding gaze in the pursuit of the Life Necessities Society.

\section{THE CASE AGAINST SCIENCE}

Scholars lecturing in and students studying Environmental Studies were generally critical of the use (or more often abuse) of science, and would actively pursue interdisciplinary "action research" as an alternative. The uses of science by their conservative, technocratic, or leftist opponents on the political spectrum were often informed by a single discipline, they would argue. They envisioned instead that environmental research would bypass the pitfalls of the Cold War socio-political divide by being interdisciplinary. Science should mirror nature's complexity and scientists should join the effort with their know-how to save the environment through research aimed at solving practical issues. Thus understood, the interdisciplinary action research of Environmental Studies was an effort to find environmentally viable alternatives to the science that supported capitalist or socialist exploitations of nature. Research done without deeper questioning of social and environmental values was, to them, "shallow," hence the importance of distinguishing between deep and shallow ecology. The use of "shallow" scientific research to rationalize and objectify the exploitation of the nation's natural resources, including hydropower developments, was troubling to Environmental Studies scholars.

This sentiment with respect to science was developed in a textbook of philosophy of science published by Næss and his students in 1973. Here they argued that humanity "faces the ecological problems science creates" 
and that it was therefore urgent to find a new way of organizing science. ${ }^{2 \mathrm{I}}$ This textbook had a significant distribution as it was used in the mandatory core course in the philosophy of science that all students entering the University of Oslo were required to pass. For most students, the book would be their first academic read, creating the initial impression of academic thinking, order, and knowledge. At the end of the term, they had to take rigorous exams on the topic - which a significant number failed - before continuing in more specialized fields. Thus, for example, a student dreaming of becoming a chemist would have to study all "the negative aspects of science" and make sure to remember and stress the importance of "ecologically informed philosophical systems" when answering his or her exam questions. ${ }^{22}$

The authors were not subtle about their philosophy of science views. Indeed, they would warn the incoming new freshmen about all the awful things with which science had provided society in the past, such as weaponry, pollution, and class division. The ecologists were the exception, and ecology was the antidote. Ecologists were the do-gooders and had, as a consequence, Næss argued, a "tremendous and nearly sinister responsibility for our society's future." ${ }^{23}$ This was the general sentiment within Environmental Studies, though it is worth noting that not all the ecophilosophers agreed with Næss on the overarching importance of ecology. The graduate student of sociology Sven Erik Skønberg, for example, a longstanding member of the Ecophilosophy Group, sought to downplay the importance of ecology. This field should not be "the new big scientific unifier," he argued, as it could entail a new version of scientistic positivism he could not agree with. ${ }^{24}$

The science of ecology would change in this period, something the scholar-activists associated with Environmental Studies largely failed to notice despite their deep-seated enthusiasm for ecology. When the Norwegian contribution to the International Biological Program faded out in 1974, it marked an end to steady-state ecological research inspired by Eugene and Howard Odum. Some ecologists left the field and became

${ }^{2 I}$ Arne Næss with Per Ariansen, Thomas Krogh, and Hans Eirik Aarek, Vitenskapsfilosofi: en innføring, 2nd preliminary ed. (Oslo: Universitetsforlaget, I973), p. 3.

22 Næss with Ariansen, Krogh and Aarek, Vitenskapsfilosofi, p. 3, 63.

${ }^{23}$ Arne Næss, "Forskerens ansvar i miljøkrisen," Forskningsnytt, I7 (I972), 48-5 I, quote p. 48. Republished in Næss with Ariansen, Krogh and Aarek, Vitenskapsfilosofi (1973), pp. I45-52.

${ }^{24}$ Sverre Kværner, "Når vitenskap blir økopolitikk," Universitas nr. 6/7, Apr. 26, I979, I3, UO. 
teachers or environmental bureaucrats, while those who remained on campus would turn their focus toward evolutionary ecology and sociobiology. Nevertheless, among the ecophilosophers and the staff at Environmental Studies, steady-state ecology would remain as the all-dominating view of how to understand the natural world and human-nature relationships. The idea of a steady-state society in harmony with steady-state nature would be the norm in Environmental Studies well into the I990s and beyond. The general anti-science sentiment among the Deep Ecologists may explain why new trends and perspectives in the field of ecology were not adopted or appreciated. The exception was Hofseth, who encouraged empirical environmental research as an antidote to polarized politics.

Næss would spell out his faith in ecology and disillusionment with the other sciences in his talks at Environmental Studies and later in what became one of his most famous lectures, "The Case against Science," given in May 1974 on the occasion of the 5oth anniversary of the Catholic University of Nijmegen in the Netherlands. If the Dutch commemorating listeners had expected something cheerful, they must have been disappointed. "My enthusiasm [for] science in general is gone," Næss professed. ${ }^{25} \mathrm{He}$ continued on to say, "In industrial societies science has become gigantic in scope - bureaucratic, impersonal and politically powerful," and scientists failing to take a stand on social and environmental issues were part of this technocratic system. ${ }^{26}$ Scientists, as Næss saw it, were unwilling to question authorities, enjoyed undeserved social privileges, were indifferent to non-western societies and rationalities, supported technocracies, and pursued projects that led to environmental degradation. These accusations against the sciences became widely discussed in Norway, and beyond. ${ }^{27}$

One of the debaters was the philosopher of science Paul Feyerabend (1924-94), who had become an acquaintance of Næss after attending a seminar in 1955 at the Ustaoset resort (close to Næss's cabin) at which he "refuted" Næss's Interpretation and Preciseness (1953) for its scientism. ${ }^{28}$

${ }^{25}$ Arne Næss, “The case against science," in C. I. Dessaur (et al., eds.), Science between Culture and Counter-Culture (Nijmegen: Dekker and van de Vegt, I975), pp. 25-48, quote p. 26, Næss's emphasis.

${ }^{26}$ Næss, "The case against science," p. 27.

27 Arne Næss, Anklagene mot vitenskapen (Oslo: Universitetsforlaget, I980).

${ }_{28}$ Paul Feyerabend, "Remarks on Interpretation and Preciseness" (1955), in Nina Witoszek and Andrew Brennan (eds.), Philosophical Dialogues: Arne Noess and the Progress of Ecophilosophy (Lanham: Rowman and Littlefield, I999), pp. 50-6, quote p. 56. Næss. Interpretation and Preciseness. 
Næss enjoyed thoughtful criticism of his work, and he would over the years encourage Feyerabend to publish his thinking in the journal Inquiry, which Næss edited. The result was, perhaps, Feyerabend's most wellknown article, namely "'Science': The myth and its role in society" (1975). ${ }^{29}$ Here he spelled out, in no uncertain terms, the anarchist nature of science in which there is no shared or unifying method. To which Næss replied (in the subsequent pages of the same issue) that "science could serve anarchists too" if research was used to benefit the counterculture and the environmental cause. ${ }^{3 \circ}$

The problem with Feyerabend's anarchist philosophy and more generally, the counterculture reaction against the scientific community's entanglement with weaponry and industrialism, as Næss saw it, was the all-encompassing dismissal of science without consideration of the few good disciplines in science. In "The Case against Science" Næss argued that certain sciences, particularly ecology, could provide constructive paths for alternative ways of organizing nature and the world. As an example, he pointed to the Deep Ecologists which tended "to give greater priority to action research - relatively short-term, goal-directed, informal investigations directed toward solving practical problems on the way toward a true bio community in ecological equilibrium." ${ }^{3 \mathrm{~T}}$ These ideals reflected core values within Environmental Studies. Here scholars would aim at action-research that would drive Norway to become an alternative nation in ecological equilibrium:

A society in ecological equilibrium will probably have to eliminate many privileges. Even at the expense of professional efficiency, students and staff may have to partake in primary production. It is expected that this will also have a beneficial effect upon the prevailing ideology. It may further the basic ecological aim of making life complex rather than complicated, that is, of developing all faculties and opportunities, living in a rich local environment requiring many and varied kind of activity, and on the whole obliterating the strict separation of work and leisure. ${ }^{32}$

Kvaløy and the circle of activists that came to surround him were the philosophical architects of this statement by Næss, and it is telling of the

${ }^{29}$ Paul Feyerabend, “'Science:' The myth and its role in society,” Inquiry, I 8 (I975), I 67-8I.

30 Arne Næss, "Why not science for anarchists too? A reply to Feyerabend," Inquiry, I 8 (1975), I83-94. See also, "Paul Feyerabend: A Green Hero?" in G. Munevar (ed.), Beyond Reason (Dordrecht: Kluwer, I99I), pp. 403-16.

${ }^{31}$ Næss, "The case against science," p. $46 . \quad{ }_{32}$ Næss, “The case against science,” p. 46. 
type of thinking and research that took place among scholars associated with Environmental Studies.

Because of their skepticism of science, Environmental Studies scholars tried to avoid traditional academic hierarchies when they pursued research. Research was not done for its own sake, but aimed instead at solving practical environmental problems. Faculty, staff, and students would merge themselves into action research trying to develop environmental approaches or technologies that could help the world. A telling example was the construction of a successful hot-water solar heating unit on the roof of the Department of Biology building. ${ }^{33}$ This technology was innovative and received national attention, as well as recognition from the Deep Ecologists. ${ }^{34}$ This is worth mentioning, as it indicates that students informed by ecophilosophy did not shy away from addressing "shallow" technological answers to energy questions. Such technologies were not seen as solutions to the ecological crisis, but as integral parts of a larger vision of an alternative nation. In 1977 , for example, the students of the Environmental Studies seminar devoted all their combined efforts to study energy, publishing a report on the need to identify, manage, analyze, and explore alternative sources for energy so that Norway could be an alternative ideal for the world to admire. ${ }^{35}$ This effort to develop practical solutions as a means for realizing an eco-friendly world was also evident in a new course offered from 1978 which focused on how to save energy in private homes by means of solar heating and other unconventional sources. ${ }^{36}$ Staff and students would also do action research on other issues, such as "the ecological crisis in Sahel," arguing that this region of Africa was in urgent need of developmental aid of a kind that did not do environmental harm to the dry semi-desert. ${ }^{37}$ Another project was action research addressing why outdoor life values and interests were ignored in the decision-making processes leading to hydropower developments. ${ }^{38}$

33 Rolf Ottesen, "Vellykket solenergiforsøk," VG, Sept 22 I975, UO. Anonymous, "Solen en enorm ressurs: Vellykket forsøk i Norge," Adresseavisen, Sept. 23, I975, UO.

34 Anonymous, "Miljøteknologiske prosjekt," (snm)-nytt, 6 (I977), 22.

35 Arild Hervik (et al.), Energianalyser: energiforbruket ved framstilling og distribusjon av matvarer (Oslo: Rådet for natur og miljøfag, I977).

${ }^{36}$ Olav Benestad, Kurs om energi og energisparing (Oslo: Rådet for natur- og miljøfag, 1978).

37 Jan Borring and Per Houge, Den økologiske krisen i Sahel (Oslo: Rådet for Natur og Miljøfag, I975).

${ }^{38}$ Ivar Mytting and Rasmus Hansson, Friluftsliv i konsesjonsbehandling av vassdragssaker (Oslo: Rådet for natur- og miljøfag, approx.r980). 
Hofseth and his colleagues were involved in action-research groups with students addressing questions related to pollution, urban planning, and public transport. ${ }^{39}$ Other action researchers found out why hydropower developments and oil drilling were damaging to rural regions. According to Vinje, rural communities should instead help and support the self-sufficient fishermen-peasants..$^{40}$ Another Environmental Studies report noted that oil exploration was the chief underlying cause for social unrest and should thus be viewed with suspicion. ${ }^{4 \mathrm{I}}$ With major discoveries of oil in the North Sea, scholars at Environmental Studies tried to halt further exploration as they firmly believed petroleum would take Norway away from the ecopolitical path of showcasing an environmental alternative to the destructive forces of the European Community and capitalism. ${ }^{42}$ The same was true for the nation's hydropower-hungry aluminum industry. ${ }^{43}$ In the humanities, an action research milestone for Environmental Studies was the first Norwegian environmental encyclopedia being published in $1976 .{ }^{44}$

Ecophilosophical perspectives and ecology were at the heart of all this action research. "Environmental Studies for Ecopaths" (in analogy to sociopaths or psychopaths) was a journalist's telling description of the institution in the fall of 1977. The "hard working" students were in an unusually "stressful environment," he noted. ${ }^{45}$ Apparently, none of the students had seen Hofseth, their chief advisor, for months, as he was traveling around the world with the good news about all the action research in Norway.

\section{EDUCATION IN ECOLOGICAL DOGMATISM}

Between 1972 and I975, about fifteen teaching assistants and ten project-based employees had been working within the temporary ad-hoc

39 Anonymous, "NSU Krets, møtereferat," May 22, I973, ms. 2 pages, PH. Olav Benestad, "Innstilling om nærtrafikken i Oslo-området," Mar. 29 I97I, ms. 2 pages, PH.

$4 \circ$ Arne Vinje, "Distriktsnedbygging eller auka sjølberging?" Miljømagasinet, 5 (I973), 32-4; "Norsk økopolitikk: Fram for auka sjølberging," Miljømagasinet, 4 (I973), $30-2$.

${ }^{4}$ Paul Hofseth and Harald Celius, Sosiale konsekvenser av oljevirksomhet i Skottland (Oslo: Rådet for natur og miljøfag, I975).

$4^{22}$ Karina Vogt, "Hard kamp om oljeboring nord for $62^{\circ}$," Universitas nr. I $2 / \mathrm{I}_{3}$ I 976 , I7, UO.

43 Reidar Eriksen, Per Halvorsen, and Steve I. Johansen, Aluminiumsindustriens framtid (Trondheim: Universitetet i Trondheim, I977).

44 Ragnar Frislid, Paul Hofseth, and Johan Støyva (eds.), Miljøleksikon: Økologi, natur- og miljøvern (Oslo: Stiftelsen NKI, 1976).

45 Terje Albregtsen, "Rådet for økopate," Universitas, Io/I I (I977), I 2, UO; "Frå England til Kaukasus," Universitas, Io/I I (I977), I 5, UO. 
Environmental Studies facilities, reflecting a "green wave" of students eager to join the field. ${ }^{46}$ By then Environmental Studies was ready to hire staff, create new courses, and begin various environmental research programs. ${ }^{47}$ The time was ripe for long-term planning, research applications, and new appointments. The institution would solidify its position within the University with a new ordinance in $1975,{ }^{48}$ and eventually become a permanent institution in $1976 .{ }^{49}$

In the same period Næss noticed that people working at Environmental Studies had begun to harden their positions, and that the debates among the ecophilosophers often lacked the subtleties he had appreciated within the Nature and Humans seminar back in I970. Næss too would gradually adopt a more dogmatic position. As he told his friend Alfred J. Ayer, the British philosopher and logical positivist, in a radio interview in 1974: "When we believe that we really must do something about some terrible pressing problem, we must somehow narrow down our perspective. [... Students] need rhetoric and dogmatism, I think. Scepticism breeds passivity. I do not feel that way, but the students do." ${ }^{\circ}$ Indeed, ecological rhetoric and dogmatism is an apt description of what the educational program at Environmental Studies came to be.

The educational program at Environmental Studies began with the core course Nature and Humans. It had the same title as the seminar the Ecophilosophy Group organized at the Philosophy Department in I970 (see Chapter 3 ). The course should thus be understood as a continuation of the Group's seminar. Hofseth had a warm and inclusive personality and he used the course to bring the Group together again, both socially and intellectually. He invited them, along with other Deep Ecologists, to be guest lecturers and seminar leaders from wherever they were based, most frequently from within the University. ${ }^{5 \text { I }}$

Many students were complaining that the Examen philosophicum required core courses for all freshmen students in logic and the history

${ }^{46}$ Kjell Jørgensen,”Grønn bølge,” VG, July 26, I975, UO.

47 Anonymous (interview with Paul Hofseth), "Miljøfagsundervisningen ved Universitetet i Oslo," Nytt fra Universitetet $i$ Oslo, I3 (I974), I-2, UO.

$4^{8}$ Anonymous, "Reglement for Rådet for natur- og miljøfag," Nytt fra Universitetet i Oslo, 8 (1975), 4, UO.

49 Anonymous," Rådet for natur- og miljøfag er blitt permanent," Nytt fra Universitetet $i$ Oslo, 6 (1976), 3-4, UO.

${ }^{5 \circ}$ Næss quoted in a debate with Alfred J. Ayer in Fons Elders (eds.), Reflexive Water: The Basic Concerns of Mankind (London: Souvenir Press, I974), 26.

${ }^{51}$ Hjalmar Hegge, "Økologi og filosofi," Forskningsnytt, 4 (I973), 54-6. 
of philosophy were too narrow or irrelevant. Students in the natural sciences were particularly upset. Why should a young freshman dreaming about becoming a geologist study Plato? In I973, in an attempt to answer these critiques, the exams were modified so that students could choose between different philosophical topics, in addition to courses in logic and the history of philosophy. These were "Primary Sources in Philosophy," "Practical Argumentation," "Contemporary Philosophy," and "Nature and Humans." ${ }^{22}$ The last course was geared toward the displeased science students, and Environmental Studies became the institutional home for the course. As it was one of the University's core courses, a steady flow of freshmen arrived at Environmental Studies. To most of them it was their first impression of academic life. Nature and Humans became a popular course and Environmental Studies would soon struggle to find adequate teaching facilities to house all their students. ${ }^{53}$ The course grew in size from around Ioo students in 1973 to about 300 by 1982 . Within that decade more than 2,000 students had received credits from taking the Nature and Humans course. ${ }^{54}$

When Nature and Humans was offered for the first time in the fall of I973 it received national attention. Months before the semester began, the press wrote about it, and the newspapers continued to cover its content the entire semester. ${ }^{55}$ It was the excursions into the forests near Oslo, interdisciplinary lecture series, study groups with only fifteen students, and daring curriculum that raised eyebrows and challenged traditional ideas of education. In particular its ecophilosophical focus received attention as something unique and newsworthy. In the process, the University of Oslo was portrayed, in both liberal and conservative newspapers, as a progressive institution at the forefront of research and pedagogy.

52 Thor Inge Rørvik, Historien om examen philosophicum $1675-1983$ (Oslo: Forum for University History, I999), note 367, p. 235.

53 Anonymous, "Miljøfagundervisning ved Universitetet i Oslo," [interview with Paul Hofseth], Nytt fra Universitetet $i$ Oslo, I3 (1974), I-2, UO; "Rådet for natur- og miljøfag er blitt permanent," Nytt fra Universitetet $i$ Oslo, 6 (I976), 3-4, UO.

54 Ola Glesne, "RNM Undervisning," ms. I3 pages, n.d. [early I990s], PA.

55 J. B., "Forberedende øko-filosofi," Adresseavisen, June 2 I I973, UO. John Baardsgaard, "Forbredende økofilosofi,” Morgenbladet, Aug. 2, I973, UO. A. M. R., “3700 til Oslo for å immatrikuleres," Morgenbladet, Aug. 29, 1973, UO. Anonymous, “Auditorium i Marka," Aftenposten, Oct. I, I973, UO. Anonymous, "Miljøundervisning for nye studenter," Aftenposten, Sept. 27, I973, UO. Anonymous, "Seminar om natur- og miljøvern," Hallingdølen, Nov. 2, I973, UO. 
Hofseth was the prime architect of the Nature and Humans course. The syllabus from the first semester in the fall of 1973 has been lost. Judging from the subsequent catalogue, the lecture list included, besides Kvaløy, Næss, and Faarlund, two philosophers, an agriculturalist and boat builder, a historian of philosophy, and three ecologists. They were all associated with the Ecophilosophy Group, critical of the European Community and hydropower developments, and opponents of the construction of the Mardøla plant. The ideological uniformity of the course is what held its interdisciplinary content together. Hofseth would also include scholars who happened to be in town as visiting lecturers, such as the Swedish biologist and environmentalist Georg Borgström to discuss his book The Hungry Planet. ${ }^{56}$

The syllabus consisted of Næss's book and Kvaløy's manuscript, along with the course reader, Økofilosofisk lesebok (Ecophilosophical Reader), which was adorned with a drawing by Kvaløy from the Mardøla demonstration and the motto "COMPLEXITY AGAINST COMPLICATION" on the cover (figure 5). As Kvaløy saw it, the "complexity" of the ecological world was resisting the one dimensional "complication" of the industrial world. ${ }^{57}$ The drawing shows rows of metal plates being laid upon a pristine landscape with small picturesque farms and the Mardøla Waterfall in the background. In the midst of the drawing one can see the do-gooding environmental activists with their tents trying to halt the advance of industrialism by means of non-violent dialogue and demonstrations.

In the Nature and Humans reader students would study whether or not the ancient Greeks lived in ecological harmony (they did) ${ }^{58}$, whether the Scripture conveyed ecological wisdom (it did) ${ }^{59}$, and whether "standard

${ }^{56}$ Lecturers included the philosophers Jon Wetlesen and Haftor Viestad, the agriculturalist and boat builder Jon Boyer Godal, the historian of philosophy Hjalmar Hegge, and the ecologists Henning Dunker, Magnar Norderhaug, and Ivar Mysterud. George Borgstrøm, Mat for milliarder (I962) (Oslo: Gyldendal, I968).

57 Sigmund Kvaløy, "Økofilosofi som forståelsesnøkkel," in Paul Hofseth (ed.), Økofilosofisk lesebok, vol. I (Oslo: Samarbeidsgruppa for natur og miljøvern, I974), ms. I6 pages. Øystein Nesje, "Økofilosofisk lesebok" (review), Miljømagasinet, 6 (I974), 30 .

${ }^{58}$ Hans Eirik Aarek, "Gresk naturoppfatning og vitenskap," in Paul Hofseth (ed.), Økofilosofisk lesebok, vol. 2. (Oslo: Samarbeidsgruppa for natur og miljøvern, I974), ms. 20 pages.

59 Gunnar Breivik, "Læren om Gud og det store huset: (teo-logi og øko-logi)," in Paul Hofseth (ed.), Økofilosofisk lesebok, vol. 2. (Oslo: Samarbeidsgruppa for natur og miljøvern, I974), ms. I7 pages. 


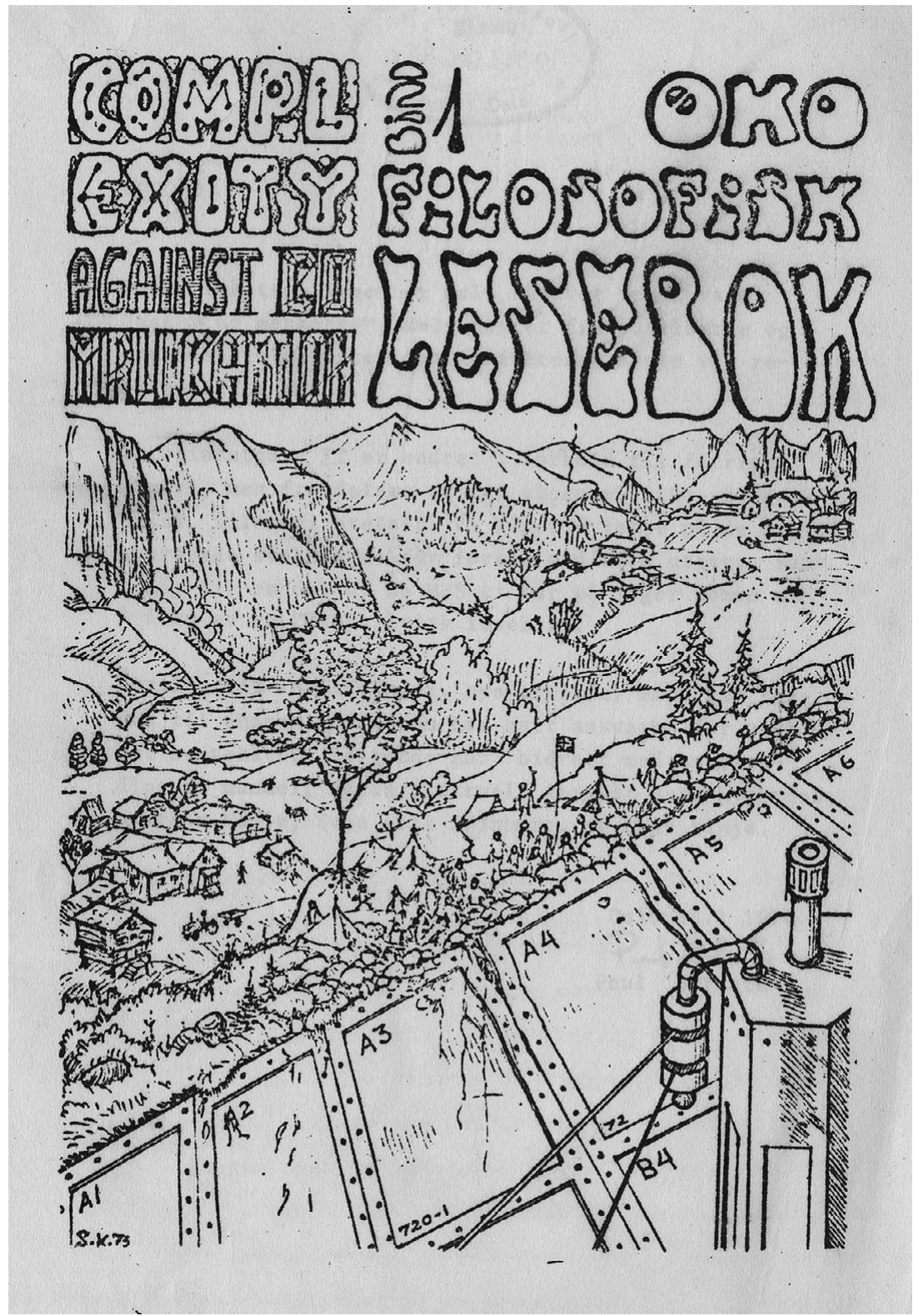

FIGURE 5 The front-page of the Ecophilosophical Reader used in the Nature and Humans course. Drawing by Sigmund Kvaløy, 1973.

Courtesy of the University of Oslo Archive 
of living" was the same as "quality of life" (it was not) ${ }^{60}$, to mention just a few of the topics on the syllabus in addition to other ecophilosophical readings by Kvaløy, Næss, and Peter W. Zapffe. In addition to all the male authors there was also a female anthropologist who upheld the ecological outlook of Fredrik Barth (see Chapter I) ${ }^{6 \mathrm{I}}$ The entire semester was introduced by a lecture on the science of ecology by Ivar Mysterud that captured the basic elements of the Odum brothers' ecosystem methodologies for nature and society. ${ }^{62}$ The virtue of outdoor life was at the heart of all the articles, which, according to an external reviewer, were anything but an easy read. ${ }^{63}$ The underlying questions in these readings were about how to formulate a good, viable, environmental alternative to the destructive powers of the world, namely the European Community, NATO, the Soviet Union, and the United States. Scholars who supported one of these powers were generally not welcomed as lecturers or as authors for the reader in Environmental Studies.

One such example was the Marxist urban planner Erling Amble, who was not invited to make his case against ecophilosophy and eco-politics in the students' reader. Another was the geologist Ivan Rosenqvist, who was invited to lecture only once or twice and whose many articles were not included in the syllabus. The reason was simple. They represented the Marxist-Leninist line of reasoning that was behind the onslaught on the Deep Ecologists. Yet instead of inviting the Marxists to make their case in the reader or in the classroom, the Nature and Humans course focused on ecophilosophical topics and declined to engage with their critics.

Anfinn Stigen, the classicist, may also serve as an example of a scholar who was not included in Environmental Studies' inner fold. He was an Associate Professor at the Department of Philosophy and was involved in developing and teaching the Examen philosophicum curriculum. "There must be an expansion of the humanistic and culture conserving disciplines at the expense of the natural sciences," he argued back in I97I. Ecology

${ }^{60}$ Hjalmar Hegge, "Livskvalitet og levestandard,” in Paul Hofseth (ed.), Økofilosofisk lesebok, vol. 2. (Oslo: Samarbeidsgruppa for natur og miljøvern, I974), ms. 7 pages.

${ }^{61}$ Ingrid Rudie, "Økologi og kultur," in Paul Hofseth (ed.), Økofilosofisk lesebok, vol. I. (Oslo: Samarbeidsgruppa for natur og miljøvern, I974), pp. I I0-31;Visible Women in East Coast Malay Society (Oxford: Oxford University Press, 1994).

${ }^{62}$ Ivar Mysterud, "Noen økologiske grunnbegreper," in Paul Hofseth (ed.), Økofilosofisk lesebok, vol. I. (Oslo: Samarbeidsgruppa for natur og miljøvern, I974), ms. 48 pages. Eugene P. Odum, Fundamentals of Ecology, 3rd ed. (Philadelphia: Saunders Co., 197I). Howard Odum, Environment, Power and Society (New York: Wiley, I97I).

${ }^{63}$ Øystein Nesse, “Økofilosofisk lesebok,” Miliømagasinet, 5 (I974), 3 I; “Økofilosofisk lesebok,” Miljømagasinet, 6 (I974), 30. 
should be an exception, as this field addressed both natural and human needs. He worried about there being too much biology in ecological research, and therefore thought the philosophers should be in control: "Ecology should be a university discipline, and it is natural that it falls under the field of philosophy." 64 That Stigen thought ecology should be taught as a subfield of philosophy is surely evidence of the importance of ecological thinking at the Department of Philosophy which, in I97I, included the highly visible and vocal Ecophilosophy Group. There were also more pragmatic reasons for Stigen's endorsement of ecology. Perhaps it could be a remedy for displeased natural scientists criticizing the mandatory Examen philosophicum courses for paying too much attention to the history of philosophy? To prove his case he set out to write a textbook on the history of human relations to nature that would be used for the new Nature and Humans course at Environmental Studies. The first draft, Mennesket og naturen (Humans and Nature, I973), was inspired in style and content by Clarence Glacken's famous Traces on the Rhodian Shore (I967), and sketched out the history of what mostly philosophers had said about human relations to nature since ancient times. ${ }^{65}$ As a synopsis of the history of Western intellectual history, it is a remarkable manuscript that easily surpasses similar books in Norwegian at the time. Indeed, within the next decade, Stigen's manuscript evolved into his two-volume masterpiece Tenkningens historie (History of Thinking, I983), a textbook in the history of science and philosophy that over the years has been read by hundreds of thousands of students in Norway preparing for their Examen philosophicum. ${ }^{66}$

Despite Stigen's success and importance, his work (in the form of a short article) was on the syllabus for only the first year at Environmental Studies. ${ }^{67}$ The reason was quite simple. He was not in the Ecophilosophy Group's inner circle that once took over Næss's Nature and Humans seminar, his lectures and work did not directly address the

${ }^{64}$ Karl Gåsvatn (interview with Anfinn Stigen), "Menneskeverd og miljø viktigere enn naturvitenskap," Vart land, May i 8, I971, UO.

${ }^{65}$ Anfinn Stigen, Mennesket og naturen, ms. 308 pages, I973, NB. Clarence J. Glacken, Traces on the Rhodian Shore: Nature and Culture in Western Thought from Ancient Times to the End of the Eighteenth Century (Berkeley, CA: University of California Press, 1967).

66 Anfinn Stigen, Tenkningens historie, 2 vol. (Oslo: Gyldendal, I983).

${ }^{67}$ Anfinn Stigen, "En del hovedpunkter i forelesning 'mennesket og naturen' holdt for examen philosophicum studenter september 1973." In Paul Hofseth (eds.), Økofilosofisk lesebok, vol. 2 (Oslo: Samarbeidsgruppa for natur og miljøvern, I974), ms. 7 pages. 
ecological crisis, and he did not deliver a clear ecophilosophical message about the evils of the industrial society and the European Community. Finally, he adopted an anthropocentric understanding of human relations with nature in line with the thinking of the philosopher Immanuel Kant. Thus, he failed to adhere to the social and ideology matrix of Environmental Studies.

A philosopher who did conform was Hjalmar Hegge. With an interest in Johann Wolfgang von Goethe, subjectivism, and the importance of colors to perception, he was a part of the Ecophilosophy Group from its inception. Following German philosopher Jürgen Habermas, he was among one of several thinkers that criticized positivist philosophy and managerial politics based on natural sciences. ${ }^{68}$ To him, ecology was a scientific approach to the world that avoided the pitfalls of reductionist mechanical sciences as it (he believed) encompassed secondary sense perceptions such as smell and colors. Unlike atomistic sciences that lead to an unfortunate objectification of humans as manageable individuals in society, ecology offered a unified view of humans as active agents in both nature and society. Hegge set out to show that only an ecologically informed philosophy could offer a viable way out of the environmental crisis. ${ }^{69}$ Like Stigen, Hegge also wrote a textbook for the Nature and Humans course. Unlike Stigen's manuscript, it was accepted as a textbook, and the book also became popular with the wider public. Mennesket og naturen: Naturforståelsen gjennom tidene - med scerlig henblikk på vår tids miljøkrise (Humans and Nature: Understandings of Nature throughout History - With a Special View on the Environmental Crisis of Our Time, 1978), as it was entitled, was a I 50-page tour-de-force of Western philosophy of science. $\mathrm{He}$ argued that the eco-crisis began with mechanist thinking of the sixteenth-century scientific revolution, and the remedy was a turn toward "soft" technology and human ecology. ${ }^{70}$ Hegge felt it important that humans had a unique niche in nature's economy, and he spent quite a lot of time modifying Kvaløy and Næss's philosophies to avoid the pitfalls of biological reductionism. "SocialDarwinism" was not the answer to the eco-crisis, he argued in a critique

${ }^{68}$ Hjalmar Hegge, “Jürgen Habermas og erkjennelsesteoriens dilemma," Norsk filosofisk tidsskrift, 4 (1969), I33-58; "Theory of Science in the Light of Goethe's Science of Nature," Inquiry, I 5 (1972), 363-86.

${ }^{69}$ Hjalmar Hegge, "Økologi og filosofi."

${ }^{70}$ Hjalmar Hegge, Mennesket og naturen: Naturforståelsen gjennom tidene - med scerlig henblikk på vår tids miljøkrise (Oslo: Universitetsforlaget, I978), I 53. 
of where the thinking of his colleagues could lead. He instead suggested a "human ecology" inspired by the German Romantics as a remedy. ${ }^{7 \mathrm{I}}$

During the first five years, while ecophilosophers and ecologists dominated the seminar intellectually, students were also exposed to a lecture on natural resource policies. ${ }^{72}$ At the time Jørgen Randers, the co-author of The Limits to Growth report from 1972, was undoubtedly Norway's most prominent environmental academic, especially with respect to resource policies. Chapter 7 will discuss at length his importance in Norway and beyond. At this stage it's sufficient to note that in the spring of $\mathrm{I} 974$ he was actively seeking a place and an audience for his research in Oslo, as he wanted to return to his hometown after his graduate studies and professorship at MIT. Environmental Studies did not welcome him and instead gave him the cold shoulder, as they deemed him to be a "shallow" technocrat and therefore an opponent of their cause. Scholars lecturing at Environmental Studies were picked chiefly on whether or not they contributed to the Deep Ecological vision for an alternative nation that the world could admire as an example of a possible harmonious global future. As a result, Randers was not on the syllabus for the Nature and Humans course.

In 1979, six years after its inception, the Nature and Humans course was reorganized and the syllabus updated to make room for more social and natural sciences on the syllabus. The reorganization was done by Skønberg, who had taken over as course coordinator. He was an ardent follower of Kvaløy, ${ }^{73}$ and he consequently sought to fashion the course so that it would be interdisciplinary but "by no means balanced ... in the sense that all or most views on an issue were being presented," as the main point of the course was to spread and engage with Kvaløy's ecophilosophical perspective. ${ }^{74}$ Consequently, the syllabus was still strongly influenced by the past. The article introducing ecology, for example, was informed by the Odum brothers' steady-state nature at a time when most ecologists were debating fresh insights by Edward O. Wilson and

${ }^{71}$ Hjalmar Hegge, "Human-økologi eller sosial-darwinisme: Veier og avveier i økofilosofien," Norsk filosofisk tidsskrift, I2, no. I (I977), I-24.

72 Jon Godal, "Litt om Ressurser," in Paul Hofseth (ed.), Økofilosofisk lesebok, vol. I (Oslo: Samarbeidsgruppa for natur og miljøvern, I974), ms. I6 pages.

73 Øystein Nesje and Sven Erik Skønberg, "Økokrisen, Norge, og vi: Intervju med Sigmund Kvaløy,” Miljømagasinet, 6 (I974), pp. 20-2, 28.

74 Øystein Nesje and Sven Erik Skønberg, "Forord," in Natur og menneske: artikkelsamling (Oslo: Rådet for natur og miljøfag, I980-82), pp. I-I2, quote p. 6. 
Richard Dawkins, ${ }^{75}$ and issues related to growth in human populations were supported by well-worn footnotes. ${ }^{76}$ Næss - who was hardly known for elegant prose - was taken off the syllabus and replaced with a more accessible text summarizing his views. "On Borneo one can find a thicket primeval forest that not even the sharpest machete can clear. That we do not have in Norway. On the other hand, we have philosophical treatises," Skønberg told his students when he explained the omission. ${ }^{77}$

New on the syllabus was a series of articles focusing on the Global South, which emphasized that students should learn from life in the nonindustrial world. The course pushed forward the view that Indigenous people lived in harmony with nature, ${ }^{78}$ they could offer an alternative view on the meaning of development, ${ }^{79}$ and they had an economy worthy of admiration. ${ }^{80}$ These claims were backed up by an account of life in Beding, Nepal, as Kvaløy knew it from his visits with Næss and Faarlund. ${ }^{8 \mathrm{I}}$ The turn toward developmental studies sought to help the Global South with ecological insights provided by thinkers from the North and reflected a new interest from students in anthropology.

Throughout the first decade of Environmental Studies, the Nature and Humans course was at its heart both socially and intellectually. It brought the institution together. Environmental Studies was also on a mission to spread the syllabus through their Deep Ecology network by establishing

75 Ola Glesne, "Noen økologiske grunnbegreper," in Natur og menneske: artikkelsamling (Oslo: Rådet for natur og miljøfag, [1979]), pp. I3-27. Edward Wilson, Sociobiology: The New Synthesis (Cambridge, MA: Harvard University Press, 1975). Richard Dawkins, The Selfish Gene (Oxford: Oxford University Press, I976).

${ }^{76}$ Ann Norderhaug and Magnar Norderhaug, "Norge og overbefolkningen," in Natur og menneske: artikkelsamling (Oslo: Rådet for natur og miljøfag, I979), pp. I 56-88.

77 Skønberg was paraphrasing a well-known aphorism by Darwin P. Erlandsen. Sven Erik Skønberg, "Norsk økofilosofi," in Natur og menneske: artikkelsamling (Oslo: Rådet for natur og miljøfag, I979), pp. 63-8I, quote p. 63.

${ }^{78}$ Harald Beyer-Brock, "Den økologiske harmonimodell," in Natur og menneske: artikkelsamling (Oslo: Rådet for natur og miljøfag, I979), pp. 243-8; "Den økologiske "harmonimodell' sett i lys av jegere og sankere, eller de såkalte naturfolk,” Naturen, 3 (I977), 99-IO3.

79 Erik Nord, "Underutvikling og utvikling," in Natur og menneske: artikkelsamling (Oslo: Rådet for natur og miljøfag, I979), pp. I89-229.

$8 \circ$ Marshal Sahlins, "Primitiv økonomi," in Natur og menneske: artikkelsamling (Oslo: Rådet for natur og miljøfag, I979), pp. 37-46.

${ }^{81}$ Sigmund Kvaløy, “Økokrise, natur og menneske,” in Natur og menneske: artikkelsamling (Oslo: Rådet for natur og miljøfag, I979), pp. 82-I I9; "Buddisme-økologi. Et tanke slektskap," in Natur og menneske: artikkelsamling (Oslo: Rådet for natur og miljøfag, [I979]), p. 249. 
similar Nature and Humans courses at other colleges in Norway. ${ }^{82}$ In this context, Vinje and Hofseth published an updated reader with a large publishing house in order to reach a national audience. ${ }^{83}$ This was done in the spirit of trying to bring about an alternative nation founded on deep ecological values. The idea was to foster a new "counter-expertise" generation of "generalists who could act upon insight and have a critical attitude" to shallow ecological thinking when leaving academia. ${ }^{84}$

In the fall semester of I974, to answer student demand, Environmental Studies created the Miliøfagsseminaret (Environmental Studies Seminar) for those seeking to advance beyond the required Nature and Humans course. It was designed so that students could study environmental issues while, at the same time, working with scholars and staff to do action research aimed at solving actual environmental problems. As a full-time semester seminar ( 16 credits by today's standard in the USA), it began with the weeklong excursion into scenic nature, giving the students an opportunity to focus their minds on the natural environment. ${ }^{85}$ From I 974 to I982, a total of I 76 students took the course. While the ecophilosophers became increasingly dogmatic in the late I970s, the seminar reflected Hofseth's own move toward more pragmatic, hands-on solutions to the environmental issues. The empirical and practical how-to approach made the candidates attractive for the growing body of administrative positions in the nation's emerging environmental bureaucracy.

Environmental Studies put much effort into building up this educational program in order to satisfy the growing demand in the public sector for people competent in environmental affairs. Their focus was not only on young students, but also on adult education and reeducation. ${ }^{86}$ Indeed, between 1977 and 1982 Environmental Studies offered a course

${ }^{82}$ Anonymous, "Kurs i miljøkunnskap på Distriktshøskolen,” Lofotposten, n.d. I975, UO. Anonymous, "Ny linje med særlig vekt på økologi til høsten," Sunnmørsposten, Mar. I9, I977, UO. Aage Gløen, "Refleksjoner efter kurs i natur- og miljøvernspørsmål i Oppegård," Østlandets blad, May 26, 1977, UO.

${ }_{3}$ Paul Hofseth and Arne Vinje (eds.), Økologi Økofilosofi (Oslo, Gyldendal, 1975).

${ }^{84}$ Nesje and Skønberg, "Forord," pp. 4, I 2.

${ }_{5}$ Anonymous, "God generalprøve for Miljøfagseminaret," Nytt fra Universitetet $i$ Oslo, 5, Mar. I8, 1975, 2, UO.

${ }^{86}$ Paul Hofseth, "Voksenopplæring og desentralisert miljøfagundervisning," in Lars Emmelin (ed.), Miliöverdsutbildning vid universitet och högskoler (Oslo: Nordisk ministerråd, I977), pp. 62-70. Per Arild Garnåsjordet, "Forskerutdanning i natur- og miljøfag," in Lars Emmelin (ed.), Miljöverdsutbildning vid universitet och högskoler (Oslo: Nordisk ministerråd, 1977), pp. 7 I-80. Sigmund Lieberg, Environmental Education in Nordic Compulsory Schools (Copenhagen: Nordisk ministerråd, I976). 
in environment and nature preservation for college and high-school science teachers that was attended by a total of 266 tutors. ${ }^{87}$ Scholars at Environmental Studies also wrote a report on higher education in environmental studies in Norway in which they documented - in no uncertain terms - that work done at Environmental Studies represented the vanguard of environmentalism in Norway. ${ }^{88}$

A missionary undertone or do-gooding gaze on behalf of the environment was a driving force in these writings and courses. The next chapter will discuss this religious aspiration in more detail, arguing that Environmental Studies mobilized a deep seated pietist Norwegian longing for the lost Eden.

87 Ola Glesne, “RNM Undervisning,” ms. I3 pages, n.d. [early I990s], PA.

88 Trond Knudsen, Karen Johanne Baalsrud, and Paul Hofseth, Miljøfagundervisning utover videregående skole: en oversikt over undervisningsopplegg og litteratur (Oslo: Rådet for natur- og miljøfag, I978). 